\title{
THE VISION AND CREATIVE PROCESS OF THE WRITER IN RETELLING THE SINGAPORE STORIES
}

\author{
Isa Kamari \\ isa.kamari@gmail.com
}

Architecture Design \& Commuter Infrastructure

Development Sub-Group (Adcid),

Land Transport Authority (LTA),

Singapore.

\begin{abstract}
This paper explains the vision and creative process of the writer in producing three novels entitled Memeluk Gerhana, Rawa and Duka Tuan Bertakhta. All three novels follow the development of Singapore since the arrival of Raffles up to the 21 st century. The writer's prospect is offering an alternative history by retelling parts of the history as a gleam of after thought.
\end{abstract}

Keywords: historical awareness, novel, creative process, Memeluk Gerhana, Rawa, Duka Tuan Bertakhta

\section{INTRODUCTION}

The objective of this paper is to portray the creative process in writing the three novels thus far. The novels are Memeluk Gerhana (2007), Rawa (2009) and Duka Tuan Bertakhta (2011). All the novels were first published by Ameen Serve Holdings which has a headquarter in Kuala Lumpur.

There are two significant similarities in all said novels. Firstly, Singapore is used as their backgrounds. Secondly, all three novels portray several aspects of historical awareness, specifically Singapore's history. I have summarized these novels in a series of literay work that I called "Ceritera Singapura" (Singapore Stories). 
As we all know, a general history of a country is written by authoritative persons during a specific time. The novel series "Ceritera Singapura" offers stories of alternative history based on the stories of individuals or groups of people who were not from the authoritative bodies. In other words, the retelling of this alternative history grew from the soul of the society that had gone through such history either directly or indirectly. Additionally, this retelling is based on fragmented stories that were heard and recorded by those who had experienced it.

Obviously, the aspect of historical awareness is not a sole focus or subject matter used and expanded in each of novels. Indeed, the creative process that I share will not only discuss the historical aspect but there are other aspects included in narration such as religion, politics, social life and culture. I held on to the stand point that a good novel needs to be enriched with layers of experiences and thoughts, which are created from a nonconformist, unexpected, and dynamic ways of living. Hence, this paper portrays how the aspect of historical awareness is sown with other aspects of living in a narrative spread within novels.

Before I reveal any aspect of historical awareness behind the creation of each novel, it is significant to make a connection between the concepts of "literature" and "history". Such discussion is crucial because there are similarities and differences between the two. Who are literary persons and who are historians? Is there any considerable difference between them or are they actually quite alike and close to one another from what is expected?

\section{LITERATURE AND HISTORY}

Narrative subsists on both history and literature. History is a type of story where we live and hope to continue to exist, and stories are a type of history that offers possibilities; a great history whereby the existing details for a composition has a wider scope and a non-conformation source from what has been expected by a historian. There is no story or non-story as what we understand. What exists are only narrative. In other words, history is a type of literature, whereby literature is a type of history; both have a general feature, which is narrative (Hashim, 1994).

Looking at its origin, the narrative in the writing of history and literature seems quite different. Literary persons easily reject the existing plot arrangement and start their writing with a scene or character which is further expanded with various created materials. On the other hand, historians start 
their narration with sequences containing journey or time line, whereby each time line has unchangeable events. Apart from this difference, a historian and a literary person still meet with the same problem, that is how to portray a certain situation at the beginning of a sequence of time may shape a different situation towards the ending (Hashim, 1994). The assumptions underlying the similarities are as follows:

(1) All involved events have to be suitable with the central question or certain matter, such as human, district or country.

(2) The events must be bound together in a relationship with a specific issue to touch importance of human requirements, which later clarify why the time line sequences had to be appropriately began and ended.

Therefore, narrative is somewhat like a bridge or link between history and literature that can clarify the influence and reflection of reality in both of them. The arrangement or convention of narrative is not hindrance for historians and literary persons. In fact, it opens up a path to them in creating various possibilities of story-telling or retelling of an event. Historians are unable to do anything without governing the narrative aspect, especially when the obtained facts are very few. By knowing the importance and specialty of a human, a historian can influence a certain subject. Moreover, by understanding something on thoughts, feelings and desire of a man, and also the social structure that shaped them, a historian may discover a hypothesis on why something happened in that manner. From this hypothesis, he will be able to determine which facts should be studied and how their arrangements may be portrayed. Historians who rely heavily on real or realistic documents will go through a similar process. In this relationship, up until now, there is still no measurement or suggestion to distinguish between the relation of events in literary narrative and those in history (Hashim, 1994).

Further, to determine a description as "fact" or not relies mainly on the narrative convention or explanatory style. In other words, the constituent or "reality" value may be materialized by such convention, either in history or literature. In current development of documenting history, there is an inclination to adapt sequencing or a type of plot that is typically used in literature. Clearly, the reality may be manifested by such special construction. However, since reality may not be documented, therefore, realism ceased to exist. 
All kinds of writing and essays are a type of construction. We do not imitate the world, but we create a version of it. There is no mimesis, only poesies. There is no recording, only construction. This is further emphasized by the assumption that reality is exposed and influenced by all kinds of the construction process that is made onto it. Hence, reality is also a kind of creation, a text, a linguistic convention (Hashim, 1994).

In this context, we view reality as something created in history and literature not due to the existence of events and humanity, but the existence of a clear background and time frame as well as humans' movements and their reactions in sequences that made sense. Therefore, if there is an instance whereby a bit of factual or reality clashes between the narrative made by the historians and with the ones created by literary persons, there will be a probability of the authors's interference that is led by an ideological thinking or a utopia. This also happens when the author deliberately eliminates or tampers with the historical facts in his works.

In the context of novel writing, narrative is the arrangement of events that create a story. The pattern or structure that creates the narrative has a political, sociological and psychological function. This narrative structure may be similar or different between one another. Doubtless, narrative is the basic structure of any writing. A novel comprises of broad cultural aspects and has quite a huge scope altogether. The narrative structure of a novel contains an organized plot mechanism and a comprehensive social reference which depends on the institutions within a society and its absoluteness and power. In other words, narrative may portray the political culture and system, as well as the imposing social condition at any given time within a society or country.

Other than that, a novel is also a type of culture that strengthens, refines, and clarifies its absolute status quo. An important aspect in strengthening the absoluteness of a novel not only related to the social power and governance, but it was portrayed as something that is common and imposed on, which is mutually allowing each other in the exposition of a narrative. A paradox will occur when someone forgets that the content of a narrative subject is a positive social occurrence; noble, containing the absoluteness of history and social (Said, 1993). In other words, by scrutinizing the narrative structure of a novel, we can measure how far it goes in strengthening or goes against history or status quo of any social system and administration of a country. Furthermore, the effect of history on the story may be followed to see whether or not history shaped a story or did the story attempt to alter the history. 
Historical adaptation, reinvention of history as well as retelling of stories related to the society empowers a novel to present an exposition and creation of "social space" in a text, which is a space used for social and political activities.

What becomes the basis of a social space are territory, motherland, geographical district and cultural rivalry. To ponder on issues pertaining to neighbouring land, to colonize it, to conquer or to segregate it, all of these occur due to quest for land. This geographical definition presents a mapped and imaginative portrayal, involving military institution, economy and history, or generally involving culture. It also led to the possibility of the creation for all sorts of knowledge depending on the assumed traits or the final objective of the geographical district (Said, 1993).

The implication is that the clash of culture between different races in a geographical district, or the connection and tenseness among the society members within a same race divided by the difference in a geographical district. Therefore, it may be detected and analysed by the portrayal of "social space" that is radiating in a narrative, either by the exposition of history or portrayal of literature.

In addition, authors' assumptions on a country may be influenced by stories and writings on the said country that creatively interacts with needs and customs of a narrative as well as the prudence of its author and the history. This is where the influence of a narrative on another narrative may be traced. The continuity or divergence of political or social standing of an author via the novels that he wrote in different time periods, or the influence of a written novel in another author's work, may be traced by the connection between the narrative structure in those novels.

Other than that, a literary work, especially one that talks about a nation contains disarrayed internal aspects and a densely packed political background. However, apart from all the undisputable difficulties, a literary work can be counted as assimilation or simplification, or a network of choices created by the author that has appropriate property and is much clearer than the political reality. From here, the more conjoined, mixed or complex a text, the effort to interpret it has to be proactive and specified.

Every text contains wisdom and its own teaching, just like every district in this world that has overlapping experiences and historical conflicts that are related to one another. Actually, every reading of a text should not portray a general picture to compromise the identity of a text, the author or his movements. On the other hand, it also has to allow anything possibly to 
occur within a text or to an author in order to create a point of discussion and debate.

Upon reading a text, we should be open to whatever it contained or whatever that might not be included by the author. Every cultural work of art is a vision of present, and we should connect that vision to changes of view that may be sparked in the future. Moreover, a person has to make the connection between the narrative structure with all the ideas, concepts and experiences that it contained.

Nevertheless, we cannot, and should never give an absolute legislative and political power to a novel. A novel supposedly contributes to the slow and minute political process, which explains, strengthens and sometimes upholds the opinion and attitude of a country (Said, 1993). Hence, it is important for us to scrutinize a series of novels written on distinct times and by different authors to obtain an overall and precise picture of the social and political situation that colours the culture of a society or a country.

Ideas, concepts, and principles of the author about the society and country are usually reflected in the characters of a literary work, especially that of hero and heroine. Heroes and heroines in a novel portray restlessness and determination of a society, and they are pushed with experiences that explain the limitation of desires, efforts and their self-skills. Therefore, novels usually end with the death of the heroes or heroines because their desires do not meet the requirement of the current situation, or they are not appropriate with the rise of the protagonist towards the peak of stability. The implication is that based on the study of the characters in the work of art, we may be able to extract the overall desires of the society as well as the author's principles that is either prominent or hidden in the narrative.

\section{HISTORICALAWARENESS IN THE NOVELMEMELUK GERHANA}

\section{Inspiration}

I discovered that there are few suitable Malay books have been made as reading materials for younger readers at the teenage level, especially books discussing on Malays' lives in Singapore. Therefore, I thought it was better to document part of my life experiences when I was younger in the form of short story as a reading material, if not for my own children. Coincidentally, at that time, I met with my friends from primary school. All the sweet and 
funny events and even bitter ones came into my mind, and I remembered memories from teenage period such as catching spiders, playing in the drain, stealing chickens, and peeping on couples making love and flirting of monkies.

\section{Criticism}

At the same time, my soul was touched when I realized that nowadays children of the same age do not stand on reality as what I experienced during my childhood in the village. At the present time, children are more mesmerized with the shine and glory of cyber world and media which I think is fake and dawdling.

I also realized that from the angle of documentation, there are few writings about the history of Singaporean Malay's society since independence until 1980s. This is extremely worrying because, in my opinion, the society that does not know its own history is a society which is not rooted and has a loose self-esteem and will be easily felt ostracized in life, especially in Singapore that is excessively vulnerable to the exposure of global influences. Therefore, I feel like it is my calling to contribute and add something to the corpus of writings that hinges on the history of my own society.

\section{Revelation}

Hence, I started to dig on my past experiences from primary school until my teenage years. I poured out the events when I lived in Kampung Tawakal that was surrounded by Chinese cemeteries in my stories. The shift to living in an HDB flat at Ang Mo Kio was told as honest as possible. When the short stories were completed, I expanded them to the novel. Other than that, as part of the background of the story, I referred and recalled back the world and local events such as the creation of Asean, the assassination of Kennedy, inflation that arose from the oil crisis as well as the Islamic revolution in Iran, which somehow had become the topic of discussion among the villagers and influenced our path of life at that time.

\section{Relationship}

In terms of description, I wrote as honestly as possible based on the sequences of my personal experiences. I only made alterations on the facts or characters to protect the dignity and safety of the people involved in the 
story. To achieve this goal, I have created a combination of characters and portray different backgrounds as necessary. A simple language is used so that the story flows easily and smoothly.

\section{Hope}

Memeluk Gerhana is a very dear work for me. In fact, I assumed it to be as an autobiographical novel. Among the effects that I hoped it can cause is the depiction of the weaker group who should not have a hindrance in order to desire a higher ambition in life. In this situation, a true friendship may strengthen one's self-worth and drive him forward in life. In terms of nationalism, I portrayed that harmony is crucial in order to ensure a peaceful future for the society.

In terms of historical awareness, I strived to uncover a speck of an event that was covered in the official history. I retold the story very clearly about the capture of a student group who was accused to be involved in a subversive accomplice and threatened the safety of the country. I knew that I may face a major risk by acting in such a manner because I had signed an agreement of secrecy, but the drive to tell the actual story had overcome all reasoning. Furthermore, according to my consideration, the event that happened for more than 30 years ago is no longer sensitive information for the safety of the country, but potentially become as a lesson to all. Alhamdulillah, so far I have not met with any difficulty from the said party, but I am still watchful in my next speech and actions.

\section{$\boldsymbol{R} A \boldsymbol{W A}$}

\section{Inspiration}

A friend of mine from NUS shared his academic writing on Orang Seletar. I impressed upon reading it and tried to recall any creative work of art that has been made by Singaporean Malay authors on Orang Seletar or the aborigines of a nation. As far as I could remember, this has never been done. The closest thus far is a novel entitled Darah Kedayan written by Harun Aminurrashid, who has become my mentor in creating works of art with historical influence. Therefore, there exists a need to write a novel on the history of the original aboriginals of Temasek that still remains a mystery. 


\section{Criticism}

Among the questions that arise are who the first person came to Singapore is? Why their history is forgotten now? What happened to them? Is their existence counted so trivial that their self-worth and culture are now forgotten by history altogether? Is there any contribution made by them that can be made as a lesson to us in traversing the current modern life? Answering to these questions is crucial as I realized that there are efforts from certain bodies to rewrite the Singapore's history in order to strengthen their justification that Singapore is an island of foreigners. Therefore, the aborigines' status in the island has begun to be questioned and challenged by them.

\section{Revelation}

Hence, I started to read the academic writings on Orang Laut, Orang Seletar and Orang Biduanda Kallang that made Temasek and the water territory around it as settlements. The area at Selat Tebrau obviously became the heart of their livelihood and commuted in a pau kajang between Temasek, Johor the Riau Archipelago.

I also dug the history of Singapore before and after the arrival of Raffles, apart from visiting the locations where they gathered and settled such as Sungai Seletar, Sembawang, and several other places on the northern beaches of Singapore and the shores of southern Johore.

\section{Connection}

Three generations are involved in the story of the novel Rawa. I traced back the assimilation of their lives with the Malays in terms of social, political, economy, religion, and culture from the years before the independence of Singapore until the 1980s. The assimilation certainly had created a tension for the protagonist because he witnessed his way of life slowly going to extinct and replaced by the city-folks' way of life who separated from nature. The feature that became the guide of his livelihood when paddling on the Pau Kajang was replaced by the rational approach and calculations as what were practiced by his child and in-laws who sometimes sacrificed the harmony among human being and nature. His only hope was handing down several lessons to his grandchildren so that his way of life might not entirely lose. 


\section{Hope}

Through Rawa, I attempted to remind Malays that development has its own risks and able to create negative outcomes if it carried out in such a rush, disregarding its effect on the livelihood that has been the heritage and basis to all of us. Additionally, we should be constantly reminded that something that is our rights will be lost and stolen by certain persons if we are not alert and determined to sustain such right.

In terms of historical awareness, I tried to offer a piece of Singapore's history from the perspective of the aborigines that is now slowly forgotten. Their moderate way of life still able to provide us lessons to those who dwell in the city if we are sincerely ready to learn and take the example from them.

\section{DUKA TUAN BERTAKHTA}

\section{Inspiration}

I read a thin book entitled Grand Saint of Singapore by Dr. Ghouse Khan Suratee (2008) that tells the story of a famous religious man named Habib Nuh Alhabshi. I was taken aback upon reading it when I discovered that he came to Singapore from Penang several months after Stamford Raffles discovered Singapore in 1819. Coincidentally, I was reading the work by Dr. Hadijah Rahmat entitled Antara Dua Kota (1999) that portrays the influence of Abdullah Munshi on this small island during the same period.

\section{Criticism}

Hence, there exists a question based on the assumption that probably there is a specific reason why Habib Nuh followed after Raffles to Singapore. This assumption is further strengthened by the fact that Habib Nuh was purposely invited by a Naqshbandi Sufi member named Habib Salim Bin Abdullah Ba Sumayr that resided in Singapore at that time.

Lately, my heart felt uneasy with the situation whereby a number of Malays in Singapore is decreasing. About fifteen years ago the number of Malays is about 17 percent of the total population of Singapore. It is reported that now the numbers of Malays are about 13 percent out of five and a half million of Singaporean. There are more foreigners coming in, especially from China, India and Philippine who are given nationality or permanent 
residence status. Naturally, I believe that my existence as Singaporean Malay is somewhat being threatened.

Other than that, so far there are no literary works to tell the story of the opening of Singapore by Stamford Raffles from the perspective of the local Malays. All we knew has been written by the authoritative body and portrays Raffles as a nobleman that was adulated by the society. However, from various excerpts of writing that I have read, Raffles was portrayed very differently from that assumption. As a writer, I feel it is my duty to study it further and write a novel about this matter.

\section{Revelation}

Hence, I started to study several versions about history of Raffles's arrival to Singapore in 1819. Other than scrutinizing Hikayat Abdullah, Kisah Pelayaran Abdullah (1915), and other books that offer a new perspective on Stamford Raffles that was written by the late Prof. Dr. Syed Hussein Alatas and Dr. Syed Muhd Khairudin Aljunied (2005). I also studied several books that touch on the idea of development and Malays' thoughts written by karya Dr. Shaharuddin Maaruf (1998) and Dr. Hadijah Rahmat. I was surprised when discovering that Wak Cantuk was a heroic legend of the Singaporean Malay who was living within the same period as Raffles, Farquhar, Habib Nuh, Abdullah Munshi, Sultan Hussein and Temenggung Abdul Rahman.

The historical characters offer a nourishing and interesting material in creating a novel because all of them represent specific parties and mutually influencing in the development of the history of the Singaporean Malays. Therefore, Raffles and Farquhar can be regarded as the colonizers, Habib Nuh representing the group of religious men, Abdullah Munshi as an example of intellectual group, Wak Cantuk representing the group that fought for the commoners, Sultan Hussein and Temenggung Abdul Rahman representing the royalty.

\section{Connection}

Therefore, I retold the story of the opening of Singapore according to chronological order. Half of the interactions between the characters were actual instances based on the history reports. I fabricated the other half based on the imagination that was shaped from the possibility which shall not be simply rejected, for example, the relationship between Wak Cantuk with other 
characters such as Sultan Hussein and Habib Nuh that was never documented elsewhere in the historical annotations. In terms of characterization, I tried to pattern them based on real historical information. However, there are situations whereby I shaped them based on my personal feelings' intervention, for example, the creation of comical character of Sultan Hussein in order to soothe my "anger" towards him for being too ignorant, weak and greedy until he became the victim of scam and exploitation of the colonialists. In terms of the portrayal of the findings from academic research, I attempted to depict it in accordance to the reported events in history. Nevertheless, there are situations whereby I created new context in order to express important information, for example, I summarized a large portion from Dr. Syed Khairuddin Aljunied's findings on the character and attitude of Raffles towards the Malays and Islam into a form of a letter from him to Resident Crawfurd, which has never happened in the actual history. Other than that, I lightened heavy historical information by borrowing the funny iconic characters of "Bujang Lapuk". Those characters functioned as the narrator and represented the commoners. Indirectly, I wanted to remind the readers that this work is merely fiction despite being based on history. I tried to be very honest on the historical facts apart from offering an imaginative narrative.

\section{Hope}

From Duka Tuan Bertakhta, I tried to expose several historical deceptions such as a portrayal of Singapore being the nesting place for pirates who were only resided by "Orang Laut" upon the arrival of Raffles, whereas there were many Malay resided the island that became the centre for regional trading at that time. I also tried to expose Raffle's character that hated Islam and was actually cunning and ruthless towards the commoners who were colonized by him, especially the Malays. I compared Raffles' character with Farquhar that was much closer and intimate with the commoners so that my story will not be deemed as anti-British or anti-colonialist.

Furthermore, I exposed the Freemason strategy in this region that centralized in Singapore and led by Raffles ever since he was in Batavia, Bengkahulu and Penang. I tried to provide a picture that Freemason had been rooted in the livelihood of the Malays since then until now. I am aware that my move might make my work of art to be categorized as a speculative work or based on conspiracy theory, which should not be taken into serious consideration. However, I am determined and optimistic that my evaluation 
and revelation are not just empty promises and should be seriously cogitated by the readers. My hope is that Duka Tuan Bertakhta may offer an alternative history to balance the official history that has been forced on us for quite some time now.

As a final goal, I looked forward that this novel somehow manages to contribute towards the preservation of the existence of Malays in Singapore.

\section{CONCLUSION}

I hope from the discussion above, we will appreciate the fact that the relationship between history and literature is indeed strong because both involve in the creation of narration in order to portray the situation, desire, struggle, disenchantment as well as the success of a society. In other words, both portray the "existence of man" within a certain period, age, era or milieu. The different is that the official history is usually written by authoritative bodies whereas the history depicted in literature exists from the heart and soul of the society.

The historical awareness aspect that is sown in the literary works also varies. In Memeluk Gerhana, we are promoted to be brave to reveal bits of hidden history in order to highlight the truth. In Rawa, we are reminded not to forget our heritage and to reflect on the contributions of the original aborigines who have been forgotten by history. In Duka Tuan Bertakhta, we are awakened and reminded to be wary of the strategy of a certain party that always wanted to dissolve the history as well as the existence of the Malays in Singapore. Besides that, this novel offers an alternative history that can be the basis to restore the racial morale and dignity that are regularly challenged and belittled by them.

In general, all three novels challenge the original history or status quo. As an author, I wished that a kind of dialogue had been raised between the original history, and the alternative history that I have presented in my works. However, I do admit that all three novels are subjective in nature and still limited in terms of assimilation and portrayal of aspects of historical awareness. Studies on these three novels should be done along with works from other novelists so that the depiction of Singapore's history can be produced in a more complete and conclusive form.

Personally, I hope to be a good student to Pak Har or Harun Aminurrashid, whom I admire as a novelist who regards history as the turning point and the centre of all his works. 


\section{REFERENCES}

A Ghani Hamid, 1998. Wak Cantuk: Drama Sebabak. Singapura: Perkumpulan Seni A Ghani Hamid dan Sulaiman Jeem, 1990. Yaacob Mohamed. Singapura: Penerbitan Wisma

Ghouse, K S., 2008. Grand Saint of Singapore. Singapura: Wardah Books.

Hadijah Rahmat, 1999. Antara Dua Kota. Singapura: Regional Training \& Publishing Centre.

Haryatmoko, 2003. Etika Politik dan Kekuasaan. Jakarta: Penerbit Buku Kompas. Hashim Awang, 1994. "Sastera dan Sejarah: Menilai Asas Hubungan antara Dua

Disiplin” dlm. Kesusasteraan Bandingan Sebagai Satu Disiplin. Kuala Lumpur: Dewan Bahasa \& Pustaka.

Isa Kamari, 2007. Memeluk Gerhana. Kuala Lumpur: Ameen Serve Holdings. Isa Kamari, 2009. Rawa. Kuala Lumpur: Ameen Serve Holdings.

Isa Kamari, 2011. Duka Tuan Bertakhta. Kuala Lumpur: Ameen Serve Holdings.

Mariam Ali, 2002. Singapore's Orang Seletar, Orang Kallang, and Orang Laut dlm Tribal Communities in the Malay World: Historical, Cultural and Social Perspectives. Singapore: Institute of Southeast Asian Studies.

Munsyi Abdullah, 1965. Kesah Pelayaran Abdullah. Singapura: Malaysia Publications Limited.

Said, E., 1978. Orientalism. London: Routledge.

Shaharuddin Maaruf, 1988. Malay Ideas on Development. Singapore: Times Books International

Shellabear, W., 1915. Hikayat Abdullah. Singapore: Methodist Publishing House. Syed Hussein Alatas, 1971. Thomas Stamford Raffles: Schemer or Reformer. Singapore: Angus \& Robertson.

Syed Muhd Khairudin Aljunied, 2005. Rethinking Raffles: A Study of Stamford Raffles Discourse on Religions Amongst Malays. Singapore: Marshall Cavendish.

(Translated by Md Syaihan Syafiq bin Mohd. Anuar) 